\title{
ETHYMOLOGICAL DOUBLETS BETWEEN FRENCH VERBS AND THEIR USE
}

\author{
Shakirov Rustam Sobirovich
}

Bukhara State University

Lecturer at the Department of Translation Studies and Linguodidactics

\begin{abstract}
This article examines the origin, use and translation into Uzbek of two French verbs that come from the same word in Latin.
\end{abstract}

Keywords: Latin, verbs, etymological doublets, academic doublets, lexical doublets, word etymology, use of verbs, translation

\section{Introduction}

As you know, every language is constantly evolving and enriching. It is no secret that one of the main sources of language enrichment is words that come from other languages, and this process can take place at different times and in different situations. Etymological doublets represent one of the oldest and broadest lexico-semantic categories. Etymological doublets are words that return to the same etymological root but have different meanings, pronunciations, and spelling in the language [3]. Like all languages, especially European languages, French has many Latin words. It would not be wrong to say that French owes twice as much to Latin [1].

Many French words are the result of evolution from classical Latin to modern French. Over the centuries of evolution, Latin words have not only lost one or more letters or syllables, that is, they have been deformed, but their scope of use has either expanded or narrowed. Sometimes two or more words can be learned from a single word in Latin. In this case, the word in classical Latin has undergone phonetic and semantic changes over the centuries. Given that change takes place in several stages, words can be learned at different times. If one of the two words is borrowed from a modified word and the other is taken from classical Latin, that is, from the original Latin, this phenomenon is called "etymological doublets." It can also be called "academic doublets" or "lexical doublets" [4].

\section{Main part}

French verbs also have "etymological doublets". For example: écouter/ausculter; hurler/ululer ; nager/naviguer ; octroyer/autoriser ; mastiquer/mâcher ; circuler/cercler ; cailler/coaguler ; livrer/libérer ; oeuvrer/opérer ; récouvrer/récupérer ; sevrer/séparer ; apprendre/appréhender ; dessiner/désigner, employer/impliquer ; peser/penser ; relier/répliquer ; souvenir/subvenir ; tâcher/taxer ; tremper/tempérer [2 ].

Well, let's start learning the verbs one by one. The most reliable French-Uzbek dictionary, created in collaboration with the Institute for Central Asian Studies, the Department of Cultural and ScientificTechnical Cooperation of the French Embassy in Uzbekistan, and published in 2008. if we do. As given in it: 
écouter vt 1. to hear, listen, listen to; écouter de la musique listening to music; 2. to listen, to obey, to obey; écouter les conseils d'un ami to follow the advice of a friend [180,1]. and: ausculter vt méd eshitib ko 'rmoq, quloq solib tekshirmoq; ausculter un malade bemorni eshitib $k o$ 'rmoq $[48,1]$. So we can partially include these two verbs in the synonym series. Why in part? This is because the meaning must not change when the words in the synonymous line are replaced, or the meaning must be partially preserved. Let's use these verbs in the sentence:

Le médecin écoute un malade - Doktor kasalni(ng so'zlarini) tinglayapti

\section{Le médecin ausculte un malade - Doktor kasalni(ng ichki a'zolarini) eshityapti}

So, écouter the verb is used to mean to hear, to listen to, or to listen to, but ausculter the verb is mainly used in medicine and should be translated as hearing the internal organs (heart, stomach).

So in both cases the ear comes as the primary mediator, but it is difficult to say that they are clear synonyms. Let's find out now. If we study the origin of words in French doublets lexicaux (lexical doublets), doublets étymologiques (etymological doublets) or doublet savant et populaire concepts. The verbs we study are lexical doublets or etymological doublets. Both verbs are derived from the Latin verb auscultare. The verb ecouter was first mastered, this verb was mastered by the common people, and over time it was used in the form auscultare $\square$ ecultar $\square$ écouter. The verb ausculter is derived from the Latin verb "auscultare" as a result of the development of science during the Renaissance in the 13th and 14th centuries. That is, one was assimilated by the people and adapted by the people to their language, and the other was later assimilated by the scholars, so they doublets savant et populaire (academic and popular doublets) are also called [5].

So these two words are completely different words. Although derived from the same word, these two verbs, in turn, continue to evolve and be used in a broad sense. Let's look at the semantics of these two verbs. First écouter we will then study the ausculter verb[6].

We use Larousse, an explanatory dictionary of the French language. Here écouter The verb is used in the following senses:

$>$ Être attentif à un bruit, à un son, à de la musique, etc., les entendre volontairement : Écouter de la musique.

$>$ Prêter attention à ce que quelqu'un dit pour l'entendre et le comprendre : Écoute-moi quand je te parle.

$>$ Être l'auditeur d'un chanteur, d'un orateur, de la radio, les entendre volontairement : J'écoute cette émission tous les soirs.

$>$ Tendre l'oreille pour percevoir le bruit produit par quelqu'un, quelque chose : Écouter le cœur battre. Écouter la pluie qui tombe.

$>$ Être attentif à l'apparition d'un bruit, à la qualité d'un son, d'une musique, d'un propos : Écouter si un enfant pleure.

$>$ Accepter d'entendre ce que quelqu'un a à dire, lui donner audience : Il n'a pas voulu m'écouter.

$>$ Tenir compte de ce que dit quelqu'un; suivre : Professeur qui sait se faire écouter de ses élèves [5],[8].

Namely: 
1. Pay attention to the noise, the sound, the song, that is, listen to them: Listen to the song

2. Listening and understanding someone: Look at me (hear and understand), I am talking to you

3. To be a singer, a speaker, a radio listener: I am a listener of this night's show.

4. Listening to the noise made by someone or something: Listening to the heartbeat, Listening to the raindrops.

5. To notice or hear any noise, sound or song: to hear a baby crying

6. Pay attention to what someone is saying: He is not paying attention to what I am saying.

7. To follow someone's instructions: A teacher can follow his students.

Ausculter The verb is used in the following cases:

Pratiquer l'auscultation d'un patient.

Examiner avec attention une situation, quelque chose, pour en repérer les points faibles, les points forts : Ausculter le marché financier.

$>$ Procéder à l'auscultation d'un ouvrage d'art [5].

Namely:

1. Carry out the patient examination process.

2. Careful monitoring to determine the strengths or weaknesses of a situation: Monitoring the situation in the financial market.

3. To look carefully at a work of art.

\section{Conclusion}

As can be seen, although the origin is the same, there is almost no connection between these two verbs, and the ear device that connects them is also in the second verb only an element of the meaning of medical verification. remains, in the remaining cases the main mediator serves as the eye or the intellect. In short, it is clear that the use of words in French is expanding, and that the concept of polysemantic is gradually becoming more common.

\section{References}

1. Balci B. et al. French-Uzbek dictionary, Tashkent 2008.

2. Chollet I., Robert J.-M., Les verbes et leurs prépositions, CLE International, 2007.

3. Antrushina G. B., Lexicology of the English language: ucheb. posobie dlya studentov, M. : Drofa, 2000.

4. http://www.academie-francaise.fr/les-doublets-etymologiques

5. https://dictionnaire.lerobert.com/

6. https://www.larousse.fr/dictionnaires/francais-monolingue/ 